\title{
Quantitative Risk Analysis for Gas (NG and NGL) Pipelines
}

\author{
Huseyin Murat Cekirge \\ Department of Mechanical Engineering, the Grove School of Engineering, the City College of the City University of New York, New York, \\ USA
}

\section{Email address:}

hmcekirge@usa.net

\section{To cite this article:}

Huseyin Murat Cekirge. Quantitative Risk Analysis for Gas (NG and NGL) Pipelines. International Journal of Environmental Monitoring and Analysis. Special Issue: Environmental Social Impact Assessment (ESIA) and Risk Assessment of Crude Oil and Gas Pipelines.

Vol. 3, No. 6-1, 2015, pp. 1-8.doi: 10.11648/j.ijema.s.2015030601.11

\begin{abstract}
By using index method and multivariable analysis, a methodology of the threat and risk of natural gas (NG) and natural gas liquids (NGL) pipelines to environment will be presented by considering total infrastructure. General concepts are introduced and explained in detail.
\end{abstract}

Keywords: Quantitative Risk Analysis, Risk Valorization, Risk Analysis of NG Pipelines, Risk Analysis of NGL Pipelines, Acceptable Risk Zones, Unacceptable Risk Zones

\section{Introduction}

A gas pipeline presents risk to individuals and environment in general. The frequencies of occurrence of threatening events and distances at which the highest probability of risk is reached are the components of the risk analysis. These components proceed to calculate the maximum individual risk for each scenario considered. Subsequently, this level risk can be compared with other daily activities that involve risk. The maximum individual risk is the increased chance of death of a person exposed to a threat in a period of time. The calculation of the maximum individual risk at $(\mathrm{x}, \mathrm{y})$ considers all threatening events that can be generated by:

- Jet Fire (Jet-Fire): It occurs when there is continuous leakage of highly pressurized flammable gas is turned to jet fire near the point of the leak. A stream of fire generally produces thermal radiation continuous. The size of the affected area depends on the discharge rate of the gas, orientation and direction of the jet, and prevailing weather conditions at the time of the event.

- Vapor Cloud Fire (Flash Fire or Flare): The flare corresponds to the rapid ignition of a vapor cloud. It occurs in the area between the lower and upper limits of flammability of vapor cloud, where appropriate air-vapor ratio in contact with flammable source ignition causes combustion of the available mass, generating thermal radiation. It is worth noting that the mass contained in the cloud is not enough to generate overpressure.
- Vapor Cloud Explosion (Unconfined Vapor Cloud Explosion): It happens after the release of a large amount of flammable gas or vapor to atmosphere with ignition point some distance from the exhaust, causing a sudden release and violent energy in waves of pressure. A necessary condition for cloud explosion or gas pressure wave generation is caused by the presence of containment or obstruction, which favors high burning rates.

- Geotechnical stability: In the process of operation of gas pipeline, it has implemented a maintenance program to ROW (Right of Way) that is the result of assessment of the sensitivity the pipeline. It has been done an initial assessment, with which they have taken the first steps to reduce the risk from the point of view of geotechnical stability of the ROW, valuation constantly updated to ensure that maintenance activities are executed in terms of reducing the risk of gas pipeline due to geotechnical stability

The main issue in this paper is the methodology and data needed to prepare risk analysis of total infrastructure of a gas pipeline. General principles of the methodology, the specific equations, and data required to prepare a risk analysis are discussed, and an example is presented to illustrate the method.

The references considered in this paper are issued by the Federal Emergency Management Agency (FEMA) for 
emergency planning, the U.S. Environmental Protection Agency (EPA) for environmental concerns, the U.S. Department of Transportation (DOT), the U.S. Department of Commerce (DOC), and various publications by the Center for Chemical Process Safety (CCPS) of the American Institute of Chemical Engineers, [1- 14]. These principles have been modified specifically for pipelines in the context of this paper. A fundamental aim of this paper is to present an assessment method that is providing reasonable risk estimates for policy decisions and certain assumptions used are part of the paper. The methodologies presented in the paper cover pipelines carrying natural gas (NG) and natural gas liquids (NGL).

The data required for a risk analysis includes pipeline data and site data. Some information that would aid in a risk analysis is proprietary to the pipeline operator. In general, the required data include:

- The location of the proposed pipeline site, including roads and major terrain feature boundaries;

- The location of the pipeline with respect to the proposed site, and specifically the segment lying within the site;

- Land use and terrain characteristics adjacent to and within the site;

- The pipeline diameter, operating pressure, and for liquid pipelines, the product flow rate; and

- Pipeline operating history information, especially records of any previous accidental releases of product and the repair history, if available.

A phase of environmental assessment study will identify the near site and several key characteristics of a hazardous pipeline such as:

- Location;

- Product transported;

- Diameter;

- Operating pressure;

- Materials of construction; and

- Date of construction.

The paper provides for two types of calculations involving the individual risk:

- Estimating the individual risk at a specific distance from the hazard source of a pipeline segment; and

- Estimating the distance corresponding to a specified level of individual risk.

The fundamental approach in the paper is the former, as described in detail in the remainder of this section. The paper also describes the latter, which can be done through the basic process by iterating on distance as described briefly later in this section.

The steps of a risk analysis, in sequence, determine the:

1. Hazard impact distance;

2. Segment length for hazards based on the distance between the receptor and the pipeline hazard source, and the hazard impact distance;

3. Maximum mortality impact from the closest approach of the pipeline to the receptor;

4. Average mortality at the receptor for each segment,

5. Base adjusted failure probability for the pipeline;

6. Base probability for each segment;
7. Conditional probability factor for each event scenario,

8. Conditional probability of individual exposure; and

9. Individual risk at the specified locations.

Appropriate hazard consequence modeling of product releases is the basis for estimating the hazard impact distances. The scenarios apply for each of the hazard categories previously stated, i.e., flash fires, jet fires (pool fires for liquid releases), and unconfined gas or vapor explosions. The data needed for the uses of this part of the evaluation include the following:

- Product transported by the pipeline;

- Pipeline diameter;

- Pipeline operating pressure;

- Minimum distance between the pipeline and the property line (or boundary between the unusable portion and usable portion of a site, which may apply to some sites);

- Orientation of the pipeline to the property line (i.e., parallel, perpendicular, at an angle, etc.);

- Length of property line exposed to pipe length of concern, the length of the pipeline segment that lies within 500 meter of the property lines; and

- The receptor location distance as the center of the property line nearest to the pipeline.

\section{Features of Risk Assessment System}

This document contains the results of the risk analysis of technological pipeline transport system, for which a methodology has been applied to meet all specifications that are required by the risk management of the infrastructure. It has been estimated as a basis for risk valorization and as a tool for the determination of the most dangerous areas in the event of a leak or spill which has not been declared a threatening event type of fire, but for the existence of gas vapors and liquid product and predicting the effects demand to take appropriate actions. Through the methodology used, it is also to have a basis for risk management, represented by a risk value for each section of the pipeline, and defined from the threat related variables, the constructive aspects of the system and the events that may originate from third parties or natural phenomenon. The study explains step by step the aspects of the necessary methodology that the operating group responsible for maintaining the "Contingency Plan" information makes necessary modifications to update the risk analysis, and also use these results in decisions for annual investment programs, conditioning it to risk management in the system. This study initially present general aspect of risk, to facilitate understanding of the procedures and results of the methodologies employed in selection and estimation causes and risk. Such methodologies are described later and are carried thereon to application pipeline transport system. The valuation methodology is based on the universal concept of risk, in which the parameters are determined. The risk is amended through semi quantitative leveraging estimation consequences to quantitative values and qualitative assessments that define some parameters or aspects of risk. 


\section{Risk Assessment Methodology}

The methodology used is a adaptation of indexing method developed in [15] and [16] using influence distances reported for the estimation of consequences and characteristics of operation pipeline transport system. The risk variables, balance from the point of view of individual risk covered by Guidelines for Chemical Process Quantitative Risk Analysis that includes advances in Chemical Process Quantitative Risk Analysis (CPQRA), [17 - 25], are modified for using them in the analyses properly. The methodology incorporates risk valorization specific data input and output that must be updated constantly by staff in each infrastructure. It is the input characteristics that modify the risk, which are related to infrastructure, operation, maintenance, environment, prevention activities, and the characteristics of the load. These characteristics influence the frequency of a novice event, the probability of occurrence of a threatening event, the probability of producing damage in the area in which the event occurred given in the same conditions and environmental vulnerability. These characteristics will be valued for the conditions of the pipeline transport system by sector, so that each will produce a separate segmentation in the corridor. The combination of the values of these characteristics affected by factors defined for each weight results as a result a risk factor for the sector, which will be represented along the pipeline to facilitate analysis. The methodology allows the calculation of a risk value of all infrastructures per unit length, besides being able to view the areas of greatest risk along the pipeline. The risk is defined as the combination of four factors, one of which is a frequency (occurrences per unit time) and others are likely to occurrence (dimensionless values) of events that are attached in a threatening event, resulting in a risk value in terms of the occurrence of a particular damage per unit time. To facilitate risk management defines a set of characteristics that infer in the same and related infrastructure, ancillary systems, the operation, safety programs and environmental characteristics.

These characteristics determine the risk, the four factors are:

- the frequency of occurrence of an event $\left(\mathrm{f}_{\mathrm{Ei}}\right)$;

- the probability of a threatening event arising since the initiating event (PrEa);

- the probability probability of occurrence an effect with potential damage given the environment $\left(\operatorname{Pr}_{\mathrm{Ef}}\right)$; and

- the probability that a given event effect that threatening damage occurs ( $\left.\operatorname{Pr}_{\text {Damage }}\right)$.

With these values defined for each sector, probability of occurrence of damage given the vulnerability of the area. The characteristics analyzed represent damage considered in the risk assessment.

\section{Characteristics of Risk Factors of a Gas Pipeline}

The performing of valorization can be done in the following:

- identify partitions that each feature occurs along the pipe and ; and

- assign the respective values of each sector using sectorization maxima occur in the system.

Each feature referred to faith will be given a relative value, which is a number between 0 and 10 following the guidelines presented in Table 1 and considering each risk characteristic independently. Threatening events considered are fire, jet fire and explosion blaze. The unconsidered event, that is not included among these events, it is said that the event is a consequent pollution of NG and NGL scattering or dispersion of the spill. The features should be evaluated in the area of influence of the infrastructure, which is defined by the distance of influence to the situation of the pipe.

The risk factors are listed in the following table:

Table 1. Basic risk factors for $f_{E i}$

\begin{tabular}{|c|c|c|}
\hline Variable & Definition & Value $V_{C}$ \\
\hline $\mathrm{C}_{1}$ & Age of the pipe & $\begin{array}{l}20 \text { years and more }=20 \\
\text { Less than } 20 \text { years }=\text { years } / 2\end{array}$ \\
\hline $\mathrm{C}_{2}$ & Installation & $\begin{array}{l}\text { Open }=10 \text { (unprotected) } \\
\text { Open }=4 \text { (protected) } \\
\text { Buried less than one meter }=8 \text { (unprotected) } \\
\text { Buried less than one meter }=4 \text { (protected) } \\
\text { Buried more one meter }=4 \text { (unprotected) } \\
\text { Buried more one meter }=0 \text { (protected) } \\
\text { Note: The protection concerns structural coatings prevent the action of efforts. }\end{array}$ \\
\hline $\mathrm{C}_{3}$ & Protection of corrosion & $\begin{array}{l}\text { No corrosion }=10 \\
\text { One system of corrosion }=7 \\
\text { Two system of corrosion }=4 \\
\text { Three system of corrosion }=0 \\
\text { Two systems to prevent corrosion }=4 \\
\text { Three or more systems to prevent corrosion }=0 \\
\text { Note: No one considers the lining of the pipe as a system to avoid or prevent corrosion. The minimum value } \\
\text { is zero and the maximum is }=10 \text {. }\end{array}$ \\
\hline $\mathrm{C}_{4}$ & System security for pipe pressure & $\begin{array}{l}\text { Localization_1 }=8 ; \text { Localization_2 }=5 ; \\
\text { Localization_3 }=3 \text { and Localization_4= } 1 .\end{array}$ \\
\hline $\mathrm{C}_{5}$ & Dangerous activities in the area & $\begin{array}{l}\text { Intensive }=10 \\
\text { Moderate }=8\end{array}$ \\
\hline
\end{tabular}




\begin{tabular}{|c|c|c|}
\hline Variable & Definition & Value $V_{C}$ \\
\hline & & $\begin{array}{l}\text { None }=0 \\
\text { Note. Refers to construction activities planting excavation or earthworks }\end{array}$ \\
\hline $\mathrm{C}_{6}$ & Social conflicts in the area & $\begin{array}{l}\text { Terrorism }=10 \\
\text { Moderate social conflicts }=4 \\
\text { Minimal conflicts }=0\end{array}$ \\
\hline $\mathrm{C}_{7}$ & Natural disaster in the area & $\begin{array}{l}\text { Level_1 }=10 \\
\text { Level_2 }=8 \\
\text { Level_3 }=4 \\
\text { Level_4 }=0 \\
4 * \text { Number of natural threats } \\
\text { It must consider the existence of threats by movements earth phenomena hydro meteorological, erosion, } \\
\text { processes basins, seismic and volcanic processes. The minimum value is zero and the maxim or } 10 .\end{array}$ \\
\hline $\mathrm{C}_{8}$ & Maintenance & $\begin{array}{l}\text { No activity }=10 \\
\text { Moderate activity }=8 \\
\text { High level maintenance }=0 \\
\text { Note: activities should be considered as suspended pumping a sector block, operation } \\
\text { Valve, restart operations, maintenance of the pipeline, keeping valves, and auxiliary systems maintenance. } \\
\text { The minimum value is zero and the maximum } 10 \text {. }\end{array}$ \\
\hline $\mathrm{C}_{9}$ & Security inspections & $\begin{array}{l}\text { No activity }=10 \\
\text { Moderate activity }=8 \\
\text { High level inspection program }=0\end{array}$ \\
\hline $\mathrm{C}_{10}$ & Social programs & $\begin{array}{l}\text { No activity }=10 \\
\text { Moderate activity }=8 \\
\text { Some activity }=4 \\
\text { Continuous communication }=0 \\
\text { Note: Each year, the program implemented should include at least one divulgence for the community } \\
\text { capacitating in the entire area of influence. }\end{array}$ \\
\hline
\end{tabular}

In Table 2, the basis for the valuation of the characteristics referred to the likelihood of a threatening event since the beginner event; probability of an effect is present for potential damage is $\left(\operatorname{Pr}_{\mathrm{Ea}}\right.$ * $\left.\operatorname{Pr}_{\mathrm{Ef}}\right)$.

The threatening events considered are jet fire and explosion flare. If none of these events is presented, the consequent event is pollution and dispersion of NG; or spill and dispersion NGL will be actual.

The characteristics must be assessed in the catchment area of infrastructure, which is defined by the distance from involvement of pipeline conditions. Table 3 presents guidelines to assess the material characteristics of the probability of harm $\left(\operatorname{Pr}_{\text {Damage }}\right)$. With these values defined for each sector, probability of occurrence of damage is the vulnerability of the area.

Table 2. Features regarding $P r_{E a}$ and $P r_{E f}$.

\begin{tabular}{lll}
\hline Variable & Definition & Value $\mathrm{V}_{\mathbf{C}}$ \\
\hline & & $\mathrm{VC}_{11}=10 \mathrm{C}_{\mathrm{pi}} /\left(0.11 \mathrm{e}^{(7.67(\text { Dpi } / \text { Daf }))}\right)(1)$ \\
& $\mathrm{C}_{\mathrm{pi}}=$ number of infrastructures \\
$\mathrm{C}_{11}$ & $\begin{array}{l}\text { Points that may } \\
\text { cause ignition }\end{array}$ & $\mathrm{D}_{\mathrm{pi}}=$ distance of the infrastructures \\
& $\mathrm{D}_{\mathrm{af}}=$ distance of the influence \\
& $\begin{array}{l}\text { The minimum value is zero and values } \\
\text { greater than } 10 \text { will be } 10\end{array}$ \\
\hline
\end{tabular}

Table 3. Features for calculating $P r_{\text {Damage }}$.

\begin{tabular}{|c|c|c|}
\hline Variable & Definition & Value $V_{C}$ \\
\hline \multirow{4}{*}{$C_{12}$} & \multirow{4}{*}{ Exposed people } & $\mathrm{VC}_{12}=10 \mathrm{C}_{\mathrm{p}} /\left(0.80 \mathrm{e}^{(4.56(\mathrm{Dpe} / \text { Daf })}\right)(2)$ \\
\hline & & $\mathrm{C}_{\mathrm{pe}}=$ number of people \\
\hline & & $\mathrm{D}_{\mathrm{pe}}=$ distance of the people \\
\hline & & The minimum value is zero and values greater than 10 will be 10 \\
\hline \multirow{4}{*}{$C_{13}$} & \multirow{4}{*}{ Areas of environmental importance } & $\mathrm{VC}_{13}=10 \mathrm{C}_{\mathrm{aa}} /\left(0.11 \mathrm{e}^{(7.67 \mathrm{e}(7.67 \text { (Daa / Daf })}\right)(3)$ \\
\hline & & $\mathrm{C}_{\mathrm{aa}}=$ number of special areas \\
\hline & & $\mathrm{D}_{\mathrm{aa}}=$ distance of the these areas \\
\hline & & The minimum value is zero and values greater than 10 will be 10 \\
\hline \multirow{4}{*}{$\begin{array}{l}C_{14} \\
\text { For NGL pipes }\end{array}$} & \multirow{4}{*}{ Areas of emergency } & $\mathrm{VC}_{14}=10 \mathrm{C}_{\mathrm{ap}} /\left(0.11 \mathrm{e}^{(7.67 \text { (Dap/ Daf) })}\right)(4)$ \\
\hline & & $\mathrm{C}_{\mathrm{ap}}=$ number of potential areas \\
\hline & & $\mathrm{D}_{\mathrm{ap}}=$ distance of the potential areas \\
\hline & & The minimum value is zero and values greater than 10 will be 10 \\
\hline \multirow{4}{*}{$\mathrm{C}_{15}$} & \multirow{4}{*}{ Training programs } & No training activity $=10$ \\
\hline & & Moderate training activity $=8$ \\
\hline & & High level training program $=0$ \\
\hline & & $\begin{array}{l}\text { Note: A yearly program implemented and address: a strategic level divulgation two disclosures } \\
\text { and training at the tactical level and three disclosures and trainings at the operational level. }\end{array}$ \\
\hline \multirow{2}{*}{$\mathrm{C}_{10}$} & \multirow{2}{*}{ Social programs } & No activity $=10$ \\
\hline & & Compliance with some activities $=8$ \\
\hline
\end{tabular}




\begin{tabular}{lll}
\hline Variable & Definition & Value $\mathbf{V}_{\mathbf{C}}$ \\
\hline & & $\begin{array}{l}\text { Program implemented }=0 \\
\text { Note: Each year, the program implemented should address by least divulgence training to the entire } \\
\text { community area of influence. }\end{array}$ \\
\hline \multirow{3}{*}{$\mathrm{C}_{16}$} & Reporting & $\begin{array}{l}\text { Systematic reporting system }=0 \\
\text { Moderate reporting }=4 \\
\end{array}$ \\
& No reporting $=10$ \\
$\mathrm{C}_{17}$ & Alarm system & Well established alarm system $=0$ \\
& & Moderate alarm system $=6$ \\
& No alarm system $=10$ \\
\hline
\end{tabular}

\section{Risk Calculation by Sectors}

The value assigned to each feature is used to calculate the respective value of frequency or probability of each risk factor, using the formulas presented in Table 4. Risk information by sector is plotted along the length abscissa of the pipe in order to easily identify the areas of greatest risk index. The incidence values of each feature as shown in Table 5, which builds on the statistics of incidents in the transport of hydrocarbons, the U.S. Department of Transportation (DOT), [6 - 8], with adjustments for the similar activities that developed in the world.

Table 4. Calculation of risk factors.

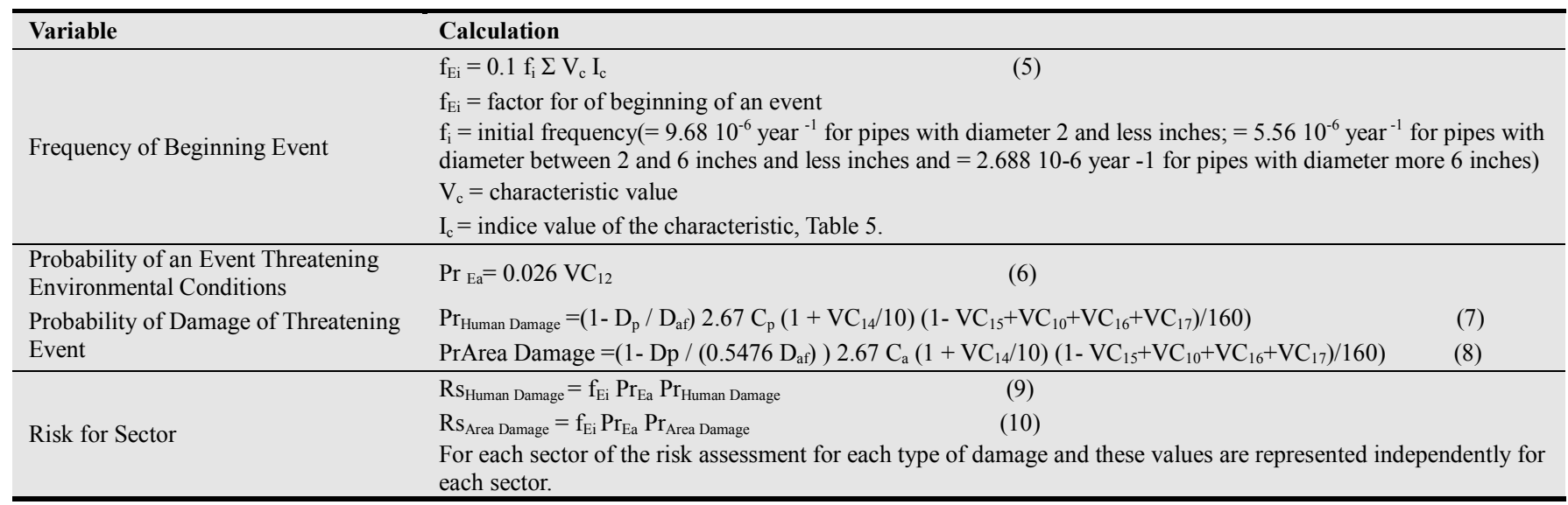

Because the input ranges are not the same, the pipeline transport system must be analyzed for the number of partitions that go to these ranges of combined characteristics of each risk factor. The value of influence distance must not be less than half of ROW (Right of Way) established for the pipeline. The influence distances are ROW for scenarios that result in lower influence distance values.

Table 5. Incidents referred to $F_{E}$

\begin{tabular}{ll}
\hline Characteristic & Indices \\
\hline Age of the pipe & 0.039 \\
Pipe Installation & 0.039 \\
Systems to avoid or prevent corrosion & 0.189 \\
Factor System Security & 0.039 \\
Threat activity in the area & 0.270 \\
Threat social & 0.270 \\
Threat natural phenomena & 0.039 \\
Procedures applied for and maintenance operation & 0.038 \\
Procedures implemented safety inspections & 0.038 \\
Programs socialization & 0.039 \\
\hline
\end{tabular}

\section{Maximum Individual Risk}

Individual risk involves the likelihood, that particular stage in a threatening event at a point $\mathrm{x}, \mathrm{y}$, is assumed for calculations that the individual is at the point $\mathrm{x}, \mathrm{y}$; for 24 hours a day, 360 days of the year, which would be the most critical situation. In numerical terms; the individual risk is defined as the probability of death of a person or a number of them, for a specific area in a year. The calculation is as shown as:

$$
\mathrm{IR}_{\mathrm{x}, \mathrm{y}, \mathrm{i}}=\mathrm{f}_{\mathrm{EA}, \mathrm{i}} \mathrm{P}_{\mathrm{f}, \mathrm{i}}
$$

where;

$\mathrm{IR}_{\mathrm{x}, \mathrm{y}, \mathrm{i}}=$ individual risk at $\mathrm{x}, \mathrm{y}$ of threat of $\mathrm{i}$,

$f_{E A, i}=$ frequency of threat $i$ in a year and

$\mathrm{P}_{\mathrm{f}, \mathrm{i}}=$ probability of effect of threat $\mathrm{i}$ to a person at $\mathrm{x}, \mathrm{y}$.

The $P_{f, i}$ is determined from the percentage of assignment given by probability and for practical purposes is equivalent to dividing by total occurring events, that is the percentage. Two terms are used in the calculation of individual risk, only the probability $\mathrm{P}_{\mathrm{f}, \mathrm{i}}$ is a function of geographic position. Therefore, the maximum individual risk is reached at point $\mathrm{x}, \mathrm{y}$; and that influence results a probability of 1.00. Mathematically, the maximum individual risk is equal to the frequency value of threatening event $\mathrm{f}_{\mathrm{EA}, \mathrm{i}}$. The total maximum individual risk at $\mathrm{x}$, $\mathrm{y}$; is given by the sum of the individual maximum risks that may arise in different scenarios and their respective threatening events: 


$$
\mathbb{R}_{\mathrm{x}, \mathrm{y}}=\stackrel{\mathrm{n}}{\Sigma} \mathbb{R}_{\mathrm{x}, \mathrm{y}, \mathrm{j}}
$$$$
\mathrm{j}=1
$$

where;

$\mathrm{IR}_{\mathrm{x}, \mathrm{y}}=$ total risk of $\mathrm{n}$ threatening effects at $\mathrm{x}, \mathrm{y}$ and

$\mathrm{IR}_{\mathrm{x}, \mathrm{y}, \mathrm{j}}=$ total risk of $\mathrm{j}^{\text {th }}$ threatening effects at $\mathrm{x}, \mathrm{y}$.

Tables 6 and 7 present the results of evaluation of risk values of pipeline transport system applying the criteria described in the paper. The values $\left(\mathrm{N}_{\mathrm{pi}}, \mathrm{N}_{\mathrm{pe}}, \mathrm{N}_{\mathrm{aa}}\right.$ and $\left.\mathrm{N}_{\mathrm{ap}}\right)$ are modifying the risk of ignition, exposed, environmental and potential areas, and their respective distances of involvement are $\left(D_{\mathrm{pi}}, \mathrm{D}_{\mathrm{pe}}, \mathrm{D}_{\mathrm{aa}}\right.$ and $\left.\mathrm{D}_{\mathrm{ap}}\right)$. The characteristics $\mathrm{C}_{11}$ to $\mathrm{C}_{14}$ are calculated through these values. The results of the other characteristics of the study assessed the risk of the product are presented in Tables 8 and 9.

By considering Tables 10 and 11, intermediate frequency of the event data likelihood of harm to people and environmental can be seen through the probability of initiating events, which are fire, blaze, and dispersion. Based on the values on these tables, the values of the total risk of affecting people and environment from NG and NGL pipelines are assessed for risk acceptability for each sector of the pipelines, Tables 12 and 13.

Table 6. Characteristics referred to initiating an event of $N G$ pipeline.

\begin{tabular}{|c|c|c|c|c|c|c|c|c|c|c|c|c|c|c|}
\hline No & Sector & $\mathrm{C}_{1}$ & $\mathbf{C}_{2}$ & $\mathrm{C}_{3}$ & $\mathbf{C}_{4}$ & $\mathrm{C}_{5}$ & $\mathrm{C}_{6}$ & $\mathbf{C}_{7}$ & $\mathrm{C}_{8}$ & $\mathrm{C}_{9}$ & $\mathrm{C}_{10}$ & $\mathrm{C}_{15}$ & $\mathrm{C}_{16}$ & $\mathrm{C}_{17}$ \\
\hline 1 & $\mathrm{KP} 0+000$ to $0+004$ & 1 & 4 & 4 & 8 & 0 & 0 & 0 & 0 & 0 & 4 & 8 & 4 & 10 \\
\hline 2 & $\mathrm{KP} 1+888$ to $1+898$ & 1 & 2 & 4 & 8 & 8 & 0 & 0 & 0 & 0 & 4 & 8 & 4 & 10 \\
\hline 3 & $\mathrm{KP} 4+264$ to $4+274$ & 1 & 2 & 4 & 8 & 8 & 0 & 0 & 0 & 0 & 4 & 8 & 4 & 10 \\
\hline 4 & KP $6+056$ to $6+764$ & 1 & 4 & 4 & 8 & 8 & 0 & 0 & 0 & 0 & 4 & 8 & 4 & 10 \\
\hline 5 & $\mathrm{KP} 8+700$ to $8+710$ & 1 & 2 & 4 & 8 & 8 & 0 & 0 & 0 & 0 & 4 & 8 & 4 & 10 \\
\hline
\end{tabular}

Table 7. Characteristics referred to initiating an event of NGL pipeline.

\begin{tabular}{|c|c|c|c|c|c|c|c|c|c|c|c|c|c|c|}
\hline No & Sector & $\mathrm{C}_{1}$ & $\mathbf{C}_{2}$ & $\mathbf{C}_{3}$ & $\mathbf{C}_{4}$ & C5 & $\mathrm{C}_{6}$ & $\mathbf{C}_{7}$ & $\mathrm{C}_{8}$ & $\mathrm{C}_{9}$ & $\mathrm{C}_{10}$ & $\mathrm{C}_{15}$ & $\mathrm{C}_{16}$ & $\mathrm{C}_{17}$ \\
\hline 1 & $\mathrm{KP} 0+000$ to $0+004$ & 1 & 4 & 4 & 8 & 0 & 0 & 4 & 0 & 0 & 4 & 8 & 4 & 10 \\
\hline 2 & $\mathrm{KP} 1+964$ to $2+341$ & 1 & 4 & 4 & 8 & 0 & 0 & 4 & 0 & 0 & 4 & 8 & 4 & 10 \\
\hline 3 & $\mathrm{KP} 4+358$ to $4+491$ & 1 & 4 & 4 & 8 & 0 & 0 & 4 & 0 & 0 & 4 & 8 & 4 & 10 \\
\hline 4 & $\mathrm{KP} 6+825$ to $6+835$ & 1 & 2 & 4 & 8 & 0 & 0 & 4 & 0 & 0 & 4 & 8 & 4 & 10 \\
\hline 5 & $\mathrm{KP} 8+788$ to $8+888$ & 1 & 4 & 4 & 8 & 0 & 0 & 4 & 0 & 0 & 4 & 8 & 4 & 10 \\
\hline
\end{tabular}

Table 8. Features regarding NG Pipeline Vulnerability.

\begin{tabular}{|c|c|c|c|c|c|c|c|c|c|c|c|c|}
\hline No & Sector & $\mathbf{N}_{\mathbf{p i}}$ & $\mathbf{D}_{\mathrm{pi}}$ & $\mathbf{N}_{\mathrm{pe}}$ & $D_{p e}$ & $\mathbf{N}_{\mathrm{aa}}$ & $\mathbf{D}_{\mathbf{a}}$ & $\mathbf{N}_{\text {ap }}$ & $\mathbf{D}_{\text {ap }}$ & $\mathrm{C}_{11}$ & $\mathrm{C}_{12}$ & $\mathrm{C}_{13}$ \\
\hline 1 & KP $0+000$ to $0+004$ & 2 & 200 & 8 & 200 & 1 & 100 & 2 & 50 & 0 & 2 & 3 \\
\hline 2 & KP $1+888$ to $1+898$ & 1 & 500 & 1 & 500 & 1 & 10 & 1 & 50 & 0 & 0 & 10 \\
\hline 3 & KP $4+264$ to $4+274$ & 17 & 225 & 67 & 225 & 1 & 10 & 1 & 50 & 1 & 8 & 10 \\
\hline 4 & KP $6+056$ to $6+764$ & 17 & 225 & 67 & 225 & 1 & 50 & 1 & 50 & 1 & 8 & 10 \\
\hline 5 & KP $8+700$ to $8+710$ & 17 & 225 & 67 & 225 & 1 & 10 & 1 & 50 & 1 & 8 & 10 \\
\hline
\end{tabular}

Table 9. Features regarding NGL Pipeline Vulnerability, $C_{14}$ are included.

\begin{tabular}{|c|c|c|c|c|c|c|c|c|c|c|c|c|c|}
\hline No & Sector & $\mathbf{N}_{\mathrm{pi}}$ & $\mathbf{D}_{\mathrm{pi}}$ & $\mathbf{N}_{\mathrm{pe}}$ & $\mathbf{D}_{\mathrm{pe}}$ & $\mathbf{N}_{\mathrm{aa}}$ & $\mathbf{D}_{\mathrm{aa}}$ & $\mathbf{N}_{\mathrm{ap}}$ & $\mathbf{D}_{\text {ap }}$ & $\mathrm{C}_{11}$ & $\mathrm{C}_{12}$ & $\mathrm{C}_{13}$ & $\mathrm{C}_{14}$ \\
\hline 1 & $\mathrm{KP} 0+000$ to $0+004$ & 8 & 200 & 8 & 200 & 1 & 50 & 2 & 50 & 6 & 6 & 10 & 10 \\
\hline 2 & KP $1+964$ to $2+341$ & 1 & 500 & 1 & 500 & 1 & 50 & 1 & 50 & 0 & 0 & 6 & 6 \\
\hline 3 & $\mathrm{KP} 4+358$ to $4+491$ & 17 & 225 & 67 & 225 & 1 & 50 & 1 & 50 & 0 & 1 & 8 & 8 \\
\hline 4 & $\mathrm{KP} 6+825$ to $6+835$ & 17 & 225 & 67 & 225 & 1 & 10 & 1 & 50 & 10 & 10 & 10 & 10 \\
\hline 5 & $\mathrm{KP} 8+788$ to $8+888$ & 17 & 225 & 67 & 225 & 1 & 50 & 1 & 50 & 0 & 0 & 4 & 4 \\
\hline
\end{tabular}

Table 10. Results of NG pipeline risk assessment, blaze values are 0.263 of fire values.

\begin{tabular}{llllll}
\hline \multirow{2}{*}{ No } & \multirow{2}{*}{ Sector } & Fire & & Blaze & Risk Environment \\
\cline { 3 - 6 } & & Risk Person & Risk Environment & Risk Person & $1.71 \mathrm{E}-10$ \\
\hline 1 & KP 0+000 to 0+004 & $5.56 \mathrm{E}-11$ & $6.46 \mathrm{E}-10$ & $1.47 \mathrm{E}-11$ & $1.84 \mathrm{E}-09$ \\
2 & KP $1+888$ to $1+898$ & $3.59 \mathrm{E}-14$ & $6.94 \mathrm{E}-09$ & $9.50 \mathrm{E}-15$ & $2.02 \mathrm{E}-09$ \\
3 & KP 4+264 to $4+274$ & $2.65 \mathrm{E}-12$ & $7.64 \mathrm{E}-09$ & $7.00 \mathrm{E}-13$ & $1.18 \mathrm{E}-09$ \\
4 & KP 6+056 to 6+764 & $2.70 \mathrm{E}-12$ & $4.47 \mathrm{E}-09$ & $7.16 \mathrm{E}-13$ & $2.02 \mathrm{E}-09$ \\
5 & KP $8+700$ to $8+710$ & $2.65 \mathrm{E}-12$ & $7.64 \mathrm{E}-09$ & $7.00 \mathrm{E}-13$ & \\
\hline
\end{tabular}


Table 11. Results of NGL pipeline risk assessment, blaze values are 0.263 of fire values, $C_{14}$ is considered for dispersion.

\begin{tabular}{llllllll}
\hline \multirow{2}{*}{ No } & \multirow{2}{*}{ Sector } & Fire & Blaze & Dispersion \\
\cline { 3 - 7 } & & Risk Person & Risk Environment & Risk Person & Risk Environment & Risk Person & Risk Environment \\
\hline 1 & KP 0+000 to 0+004 & $3.53 \mathrm{E}-09$ & $1.21 \mathrm{E}-09$ & $9.33 \mathrm{E}-10$ & $3.19 \mathrm{E}-10$ & $1.17 \mathrm{E}-08$ & $4.02 \mathrm{E}-09$ \\
2 & KP 1+964 to 2+341 & $1.29 \mathrm{E}-14$ & $2.89 \mathrm{E}-10$ & $3.42 \mathrm{E}-15$ & $7.66 \mathrm{E}-11$ & $7.86 \mathrm{E}-14$ & $1.76 \mathrm{E}-09$ \\
3 & KP 4+358 to 4+491 & $9.74 \mathrm{E}-13$ & $3.72 \mathrm{E}-10$ & $2.58 \mathrm{E}-13$ & $9.86 \mathrm{E}-11$ & $5.93 \mathrm{E}-12$ & $2.27 \mathrm{E}-09$ \\
4 & KP 6+825 to 6+835 & $1.71 \mathrm{E}-07$ & $2.16 \mathrm{E}-09$ & $4.54 \mathrm{E}-08$ & $5.71 \mathrm{E}-10$ & $4.14 \mathrm{E}-07$ & $5.21 \mathrm{E}-09$ \\
5 & KP 8+788 to 8+888 & $7.57 \mathrm{E}-13$ & $2.03 \mathrm{E}-10$ & $2.00 \mathrm{E}-13$ & $5.37 \mathrm{E}-11$ & $4.61 \mathrm{E}-12$ & $1.24 \mathrm{E}-09$ \\
\hline
\end{tabular}

Table 12. NG pipeline risk acceptability, all columns are summed.

\begin{tabular}{|c|c|c|c|c|c|}
\hline No & Sector & Risk People & Risk Environment & $\begin{array}{l}\text { Acceptability of Risk } \\
\text { Risk Person }\end{array}$ & Risk Environment \\
\hline 1 & $\mathrm{KP} 0+000$ to $0+004$ & $7.0 \mathrm{E}-11$ & $8.2 \mathrm{E}-10$ & Acceptable & Acceptable \\
\hline 2 & $\mathrm{KP} 1+888$ to $1+898$ & $4.5 \mathrm{E}-14$ & $8.8 \mathrm{E}-09$ & Acceptable & Acceptable \\
\hline 3 & $\mathrm{KP} 4+264$ to $4+274$ & $3.3 \mathrm{E}-12$ & $9.7 \mathrm{E}-09$ & Acceptable & Acceptable \\
\hline 4 & $\mathrm{KP} 6+056$ to $6+764$ & $3.4 \mathrm{E}-12$ & $5.7 \mathrm{E}-09$ & Acceptable & Acceptable \\
\hline 5 & $\mathrm{KP} 8+700$ to $8+710$ & $3.3 \mathrm{E}-12$ & $9.7 \mathrm{E}-09$ & Acceptable & Acceptable \\
\hline
\end{tabular}

Table 13. NGL pipeline risk acceptability, all columns are summed.

\begin{tabular}{llllll}
\hline No & Sector & Risk People & Risk Environment & $\begin{array}{l}\text { Acceptability of Risk } \\
\text { Risk Person }\end{array}$ & Risk Environment \\
\hline 1 & KP $0+000$ to $0+004$ & $1.6 \mathrm{E}-08$ & $5.5 \mathrm{E}-09$ & Acceptable & Acceptable \\
2 & KP $1+964$ to $2+341$ & $9.5 \mathrm{E}-14$ & $2.1 \mathrm{E}-09$ & Acceptable & Acceptable \\
3 & KP $4+358$ to $4+491$ & $7.2 \mathrm{E}-12$ & $2.7 \mathrm{E}-09$ & Acceptable & Acceptable \\
4 & KP $6+825$ to $6+835$ & $6.3 \mathrm{E}-07$ & $7.9 \mathrm{E}-09$ & Acceptable & Tolerable \\
5 & KP $8+788$ to $8+888$ & $5.6 \mathrm{E}-12$ & $1.5 \mathrm{E}-09$ & Acceptable & Acceptable \\
\hline
\end{tabular}

If the total individual risk is calculated less than the risk in traffic accidents, the pipeline can be considered as safe infrastructure and in acceptable risk zone. It should be mentioned that risk of cancer death which is $1.96 * 10^{-3}$ per year, and less than the risk of death traffic accidents is $3.9^{*}$ $10^{-4}$ per year, Table 14 .

Table 14. Individual risk of early fatality by various causes, [26].

\begin{tabular}{|c|c|c|}
\hline \multirow[b]{2}{*}{ Hazard } & \multicolumn{2}{|c|}{ Approximate Individual Risk of Death } \\
\hline & Probability / Year & $\begin{array}{l}\text { One Chance } \\
\text { in Years }\end{array}$ \\
\hline Heart Attack & $3.12 * 10^{-3}$ & 320 \\
\hline Cancer & $1.96 * 10^{-3}$ & 510 \\
\hline All Accidents & $3.90 * 10^{4}$ & 2560 \\
\hline Motor Vehicles & $1.98 * 10^{4}$ & 5030 \\
\hline Homicide & $8.66^{*} 10^{-5}$ & 11500 \\
\hline Drowning & $2.09 * 10^{-5}$ & 47600 \\
\hline Fire & $1.93 * 10^{-5}$ & 51600 \\
\hline Civil Aviation & $5.19 * 10^{-6}$ & 192600 \\
\hline $\begin{array}{l}\text { Release of gas from Wahsatch } \\
\text { pipeline/well network (risk } \\
\text { level - } 100 \text { meters either side } \\
\text { of pipeline or wellhead) }\end{array}$ & $5.20 * 10^{-6}$ & 192,300 \\
\hline Water Transport & $3.90 * 10^{-6}$ & 256000 \\
\hline Railroad Accidents & $2.56 * 10^{-6}$ & 389000 \\
\hline Lightning & $4.06 * 10^{-7}$ & 2454000 \\
\hline Bites And Stings & $2.79 * 10^{-7}$ & 3570000 \\
\hline $\begin{array}{l}\text { Release of gas from Wahsatch } \\
\text { pipeline/well network (risk } \\
\text { level - } 100 \text { meters either side } \\
\text { of pipeline or wellhead) }\end{array}$ & $2.00 * 10^{-7}$ & $5,000,000$ \\
\hline $\begin{array}{l}\text { Release of gas from Wahsatch } \\
\text { pipeline/well network (risk } \\
\text { level - } 300 \text { meters either side } \\
\text { of pipeline or wellhead) }\end{array}$ & $2.50 * 10^{-9}$ & $400,000,000$ \\
\hline
\end{tabular}

\section{Conclusions}

The introduction of qualitative risk of gas pipelines can be seen in [27], where the risk of gas pipelines was explained in detail. In this present study, the estimation of risk of a pipeline transport system is presented for assessing the individual risk and total risk based on the characteristics of the gas pipeline and its operations. These evaluations are based on results of estimation of threatening consequences of risk events identified. Individual risk assessment has its foundations in the application of procedures used in other transport infrastructure of hydrocarbon industry. In these procedures, all spill events that have occurred to date are included. In considering risk valorization characteristics of a pipeline transport system and its operations, the process valorization has been defined for individual and environmental risk. If the risk values of each infrastructure are located in acceptable risk levels, then the infrastructure could be considered acceptable. The sectors have been identified with acceptable risk for the human settlements are safe sectors of the infrastructure. In the area of human settlements, there should be divulgation activities and preparation of communities for preventive measures. The ground motions in the view of integrity of the infrastructure should be monitored by bi-annually and annually or in shorter periods through scheduled activities. The necessary updates must be introduced and included in old and new maintenance programs. 


\section{References}

[1] FEMA, Emergency Response Guidebook, 2008.

[2] FEMA, DOT, and EPA, Handbook of Chemical Hazards Analysis Procedures, US Environmental Protection Agency, US Department of Transportation, and the Federal Emergency Management Agency, 1989.

[3] United States Environmental Protection Agency (EPA), Evaluation of Dense Gas Simulation Models, Draft, EPA 450/4-90, United States Environmental Protection Agency, September 1990.

[4] United States Environmental Protection Agency (EPA), Risk Management Program Guidance for Offsite Consequence Analysis (OCAG), EPA 550-B-99-009, United States Environmental Protection Agency, April 1999.

[5] United States Environmental Protection Agency (EPA), TANKS 4.09b, Computer Program, US Environmental Protection Agency, September 1999.

[6] United States Department of Transportation Office of Pipeline Safety (DOT-OPS), Gas Pipeline Incident Database, 1984-200 1, and Hazardous Liquid Incident Database, 1986-2001.

[7] United States Department of Transportation Office of Pipeline Safety (DOT-OPS), 2000 Annual Reports for Natural Gas Transmission and Distribution Pipeline Operators.

[8] United States Department of Transportation, Research and Special Programs Administration, 49 CFR Part 192, [Docket No. RSPA00-7666; Amendment 192-95] RIN 2137-AD54, Pipeline Safety: Pipeline Integrity Management in High Consequence Areas (Gas Transmission Pipelines), ACTION: Final rule.

[9] U.S. Department of Commerce (US DOC), "Heat radiation from Large Pool Fires" NISTIR 6546, Fire Safety Engineering Division Building and Fire Research Laboratory, November 2000. Risk Assessment, American Institute of Chemical Engineers, New York, 1995.

[10] Frank Lees, Hazard Identification, Assessment and Control, Loss Prevention in the Process Industries Second Edition, 1996.

[11] Eltgroth, Mark W., "CHARM ${ }^{\circledR}$ Emergency Response System Technical Reference Manual," Radian Corporation, September 1995.

[12] Radian International, CHARM ${ }^{\circledR}$ Technical Manual, 1995.

[13] HSE, "The Effect of Explosions in the Process Industries,"
Loss Prevention Bulletin, 68:37-47, Health \& Safety Executive (HSE), 1986.

[14] HSE, Second Report Advisory Committee Ma/or Hazards, U.K Health and Safety Commission, Health \& Safety Executive (HSE), 1979.

[15] W. K, Muhlbauer, Pipeline Risk Management Manual, Second Edition, Gulf Publishing Co., Houston, TX, 1996.

[16] W. K, Muhlbauer, Pipeline Risk Management Manual, Third Edition, Gulf Publishing Co., Houston, TX, 2004.

[17] Risk Assessment, American Institute of Chemical Engineers, New York, 1995.

[18] CCPS (Center for Chemical Process Safety), Guidelines for Fire Protection in Chemical, Petrochemical, and Hydrocarbon Processing Facilities, 2003.

[19] CCPS (Center for Chemical Process Safety), Guidelines for Chemical Process Quantitative Risk Analysis, 1999.

[20] CCPS (Center for Chemical Process Safety), Guidelines for Evaluating the Characteristics of Vapor Cloud Explosions, Flash Fires, and BLEVES, American Institute of Chemical Engineers, New York, 1994.

[21] CCPS (Center for Chemical Process Safety), Guidelines for Evaluating Process Plant Buildings for External Explosions and Fires, American Institute of Chemical Engineers, New York, New York, 1996.

[22] CCPS (Center for Chemical Process Safety), Guidelines for Chemical Process Quantitative Risk Analysis, American Institute of Chemical Engineers, New York, New York, 1989.

[23] CCPS (Center for Chemical Process Safety), Guidelines for Hazard Evaluation Procedures, American Institute of Chemical Engineers, New York, 1992.

[24] Greenwood, B., L. Seeley, and J. Spouge, "Risk Criteria for Use in Quantitative Risk Analysis," in CCPS, International Conference and Workshop on Risk Analysis and Process Safety, October 2124, 1997, Atlanta, Georgia, American Institute of Chemical Engineers, New York, New York, 1997, pp. 29-40.

[25] McAllister, E. W. (ed), Pipeline Rules of Thumb Handbook, Gulf Publishing Co., Houston, Texas, 1993, pp. 497-501.

[26] John B. Cornwell and William E. Martinsen, Quantitative Risk Analysis of the Wahsatch Gas Gathering Pipeline System, Houston, Texas, 1994.

[27] Huseyin Murat Cekirge. Qualitative Risk of Gas Pipelines. American Journal of Energy Engineering. Vol. 3, No.3, 2015, pp. 53-56. doi: 10.11648/j.ajee.20150303.14 